\title{
Prevalence and risk factors for microalbuminuria in a cross-sectional study of type-2 diabetic patients in Indonesia : a subset of DEMAND study
}

\author{
Sidartawan Soegondo ${ }^{1}$, Wiguno Prodjosudjadi ${ }^{2}$, Arini Setiawati ${ }^{3}$ \\ 1 Division of Endocrinology and Metabolism, Department of Internal Medicine, Cipto Mangunkusumo General Hospital - Faculty of \\ Medicine, University of Indonesia, Jakarta \\ 2 Division of Nephrology and Hypertension, Department of Internal Medicine, Cipto Mangunkusumo General Hospital - Faculty of \\ Medicine, University of Indonesia, Jakarta \\ 3 Department of Pharmacology and Therapeutics - Faculty of Medicine, University of Indonesia, Jakarta
}

\begin{abstract}
Abstrak
Tujuan Mikroalbuminuria (MA) adalah prediktor kuat untuk nefropati diabetik serta morbiditas dan mortalitas kardiovaskular pada pasien DM tipe 2. Studi ini bertujuan untuk mengumpulkan informasi mengenai prevalensi dan faktor risiko untuk MA pada pasien Indonesia dengan DM tipe 2.

Metode Studi DEMAND adalah survei potong lintang 1 hari mengenai prevalensi MA dan faktor risikonya pada pasien DM tipe 2. Studi ini melaporkan hasil survei yang dilakukan di Puskesmas di Indonesia dari Juni sampai Desember 2003. Pasien hipertensi dan normotensi dewasa laki-laki dan perempuan dengan DM tipe 2 tanpa diketahui adanya proteinuria dan/atau penyakit ginjal diikutsertakan dalam studi. Pasien yang diketahui hamil, sedang haid atau menderita demam akut tidak diikutsertakan dalam studi. Uji albumin urin/kreatinin dilakukan satu kali pada semua pasien.

Hasil Seluruhnya ada 770 pasien yang memenuhi syarat untuk dianalisis. Sekitar $80 \%$ pasien menderita mikro-/ makroalbuminuria, sedangkan insufisiensi ginjal ditemukan pada kira-kira 36\% dari 433 pasien yang ada datanya. Target HbAlc (<7\%) dicapai hanya oleh 40\% dari 118 pasien yang mempunyai nilai HbAlc. Kebanyakan obat anti diabetes yang diresepkan adalah oral (82\%), sedangkan insulin digunakan hanya oleh 14\% pasien. Target tekanan darah (< 130/80 mmHg) dicapai hanya oleh 9\% pasien. Pasien yang menerima antihipertensi 52\%, statin 18\%, dan aspirin 26\%. Antihipertensi yang paling banyak dipakai adalah penghambat RAS (45\%), sedangkan diuretik digunakan oleh $7 \%$ pasien. Riwayat DM dalam keluarga ditemukan pada $43 \%$ pasien, riwayat retinopati $16 \%$, kaki diabetik 9\%, dan riwayat merokok pada $20 \%$ pasien.

Kesimpulan Data ini menunjukkan bahwa Indonesia mempunyai frekuensi penyakit ginjal diabetik asimtomatik yang tertinggi di antara berbagai negara yang ikut studi DEMAND di dunia. Deteksi dini, pemantauan komplikasi vaskular, dan pengobatan multifaktorial yang lebih agresif yang ditujukan untuk proteksi ginjal dan vaskular sangat dibutuhkan untuk pasien Indonesia dengan DM tipe 2. (Med J Indones 2009; 18: 124-30)
\end{abstract}

\begin{abstract}
Aims Microalbuminuria (MA) is a strong predictor of diabetic nephropathy and cardiovascular morbidity and mortality in patients with type-2 DM. The present study aimed to gather information on the prevalence and risk factors for MA in Indonesian patients with type-2 DM.

Methods The DEMAND study was an international open cross-sectional 1-day survey on microalbuminuria prevalence and its risk factors in type-2 diabetic patients. This study reports the results of the Indonesian survey which was performed in primary care practice in Indonesia from June to December 2003. Normotensive or hypertensive adult patients of both genders with type-2 DM without known proteinuria and/or kidney disease were recruited into the study. Patients with known pregnancy, having menstruation or acute fever were excluded. A single urinary albumin/creatinine test was carried out in all patients.

Results A total of 770 patients were eligible for analysis. Approximately $80 \%$ of the patients had micro-/ macroalbuminuria, while renal insufficiency was detected in about $36 \%$ of the 433 patients with available data. Target HbA1c $(<7 \%)$ was reached by only $40 \%$ of the 118 patients who had HbAlc values. Most antidiabetic treatment prescribed was oral $(82 \%)$, while insulin was used by only $14 \%$ of patients. Goal BP $(<130 / 80 \mathrm{~mm} \mathrm{Hg})$ was achieved in only $9 \%$ of patients. The frequency of patients receiving antihypertensives was $52 \%$, statins $18 \%$, and aspirin $26 \%$. The most frequently used antihypertensives were RAS blockers (45\%), while diuretics were used in $7 \%$ of the patients. The family history of DM was found in $43 \%$ of patients, the history of retinopathy in $16 \%$, diabetic foot $9 \%$, and history of smoking in $20 \%$ of patients.

Conclusion These data reveal that Indonesia has one of the highest frequencies of silent diabetic kidney disease seen in any national group in the global DEMAND Study. Early detection, monitoring of vascular complications, and more aggressive multifactorial treatment aiming at renal and vascular protection are urgently needed for Indonesian patients with type-2 diabetes. (Med J Indones 2009; 18: 124-30)
\end{abstract}

Key words: microalbuminuria, type-2 DM, Indonesia, DEMAND study 
Microalbuminuria (MA) is defined as an abnormal increase in the rate of urinary excretion of albumin to between 30 and $300 \mathrm{mg} / 24 \mathrm{~h}$. It was first described in patients with diabetes mellitus by Keen et al. in 1969. MA was also found in benign essential hypertension non-diabetic patients, but not in patients treated effectively for hypertension . Later, it was demonstrated that MA strongly predict the development of clinical diabetic nephropathy in both type- 1 and type-2 diabetes mellitus ${ }^{3,4}$. In 1997, a systematic overview of the literature showed that MA is a strong predictor of total and cardiovascular mortality and cardiovascular morbidity in patients with type- $2 \mathrm{DM}^{5}$. In non-diabetic patients, MA is also an independent predictor of vascular disease (coronary and peripheral) and allcause mortality ${ }^{6}$. Reduction in albuminuria translates to reduction in cardiovascular events in hypertensive patients treated with an angiotensin-receptor blocker . In hypertensive patients with type-2 DM and MA, an angiotensin-receptor blocker can delay the development of diabetic nephropathy, and this renoprotective effect was independent of the blood-pressure lowering effect . In patients with type-2 DM and hypertension but with normoalbuminuria, an angiotensin-receptor blocker can decrease the incidence of $\mathrm{MA}^{9}$.

In 2003, Parving et al. in collaboration with the International Diabetes Federation and the International Society of Nephrology and Bristol-Myers Squibb and Sanofi-Aventis created a study on Developing Education on Microalbuminuria for Awareness of renal and cardiovascular risk in Diabetes (DEMAND) ${ }^{10}$.

This cross-sectional global study aimed to gather information on the prevalence and risk factors for MA in patients with normo-and hypertensive type-2 DM without known proteinuria and/or non-diabetic kidney disease seen in primary care practice in various countries world-wide, including Indonesia, and to establish the correlation between the prevalence of MA and wellknown cardiovascular risk markers or factors, and also to increase physician awareness on the major importance of urinary albumin screening in order to improve patient's care. The data presented here were data from Indonesia.

\section{METHODS}

\section{Patients}

Normotensive or hypertensive men and women, aged between 18 and 80 years, with type-2 DM (World Health Organization criteria) without prior known proteinuria and/or non-diabetic kidney disease were recruited into the study. Excluded from the study were patients with type-1 DM, menstruation period, known pregnancy, and acute fever.

Concomitant medications such as cimetidine (may cause falsely elevated results with the creatinine test used in this study) and drugs containing azo dyes, nitrofurantoin and riboflavin (cause abnormal urine colour, and therefore may affect the readability of the reagent strips for urinalysis and cause false interpretation) were prohibited. Contamination of the urine specimen with soaps, detergents, antiseptics, or skin cleansers or the use of urine preservatives other than boric acid $(1.0 \mathrm{~g} / \mathrm{L})$ may also affect test results, and therefore was also restricted.

\section{Study design and procedure}

The present study was the Indonesian subset of DEMAND study. The DEMAND study was a multinational open cross-sectional 1-day survey designed to evaluate the prevalence and risk factors of micro- and macroalbuminuria in type-2 diabetic patients seen in primary care settings by random screening at each participating center during the interval from June to September 2003. Each center should enroll at least 10 eligible patients. The study was endorsed and the centers selected by local diabetes associations in collaboration with Bristol-Myers Squibb and Sanofi-Aventis.

A total of 3137 physicians in 33 different countries in Asia, Europe, Central America, South America, North America, Africa and Oceania participated. In Asia, 8 countries participated, including China, Hong Kong, Indonesia, Korea, Malaysia, Singapore, Taiwan, and Thailand.

The study protocol was approved by the ethical committee of the Medical Faculty, University of Indonesia, and written informed consent was obtained from each patient before screening.

All participating physicians and nurses received the full study protocol and the instructions to measure the urinary albumin and creatinine (single determination) and BP after $10 \mathrm{~min}$ rest in the seated position (single recording).

Patient data (gender, age, height, weight), medical diagnosis (type-2 DM : family history, duration, $\mathrm{HbA}$ the last 6 months, diabetic retinopathy and diabetic foot? hypertension : history, duration; cardiovascular risk : family history, history of smoking, hyperlipidemia), and concomitant drug therapy (antidiabetics, 
antihypertensives, lipid lowering drugs and antiplatelet/ anticoagulants) of each patient were recorded on a single page case report form.

Presence of CVD, that is left ventricular hypertrophy, coronary artery disease, myocardial infarction, congestive heart failure, stroke, transient ischemic attack, or peripheral vascular disease, was obtained from medical records and anamnesis during the interview. Presence of hyperlipidemia was also obtained from the medical records, while presence of hypertension was obtained from medical history of receiving antihypertensives.

A single urinary albumin and creatinine levels were determined using Bayer reagent strip Multistix ${ }^{\circledR} 10$ SG. According to this semiquantitative strip test, normoalbuminuria is defined as albumin-to-creatinine ratio $<30 \mathrm{mg} / \mathrm{g}$, MA $30-300 \mathrm{mg} / \mathrm{g}$, and macroalbuminuria $>300 \mathrm{mg} / \mathrm{g}$. According to the manufacturer, the Multistix 10 SG test has $88 \%$ accuracy, $84 \%$ sensitivity, and $91 \%$ specificity for albumin-to-creatinine ratio.

The estimated glomerular filtration rate (eGFR, mL/ $\min / 1.73 \mathrm{~m}^{2}$ ) was calculated using the Modification of Diet in Renal Disease 2 (MDRD 2) formula. The stages of chronic kidney disease (CKD) were defined according to the American National Kidney Foundation: stage 1 , eGFR $\geq 90$; stage 2, 60-89; stage 3, 30-59; stage 4, 15-29; and stage 5, eGFR $<15$ or dialysis ${ }^{10}$. Patients in stages 1 and 2 need to have structural or functional abnormalities of the kidney, for example, micro-/macroalbuminuria, to be classified as having kidney damage and mild stage of CKD. An eGFR $<60$ $\mathrm{mL} / \mathrm{min} / 1.73 \mathrm{~m}^{2}$ is defined as moderate stage of CKD.

\section{Statistical analysis}

Descriptive statistics (number of patients and its percentage of the total, mean and standard deviation, distribution of data) were used to analyze all data in the present study. Statistical tests were used only in the global DEMAND study to compare data from various countries, but not in the subsets of the study.

\section{RESULTS}

A total of 770 patients were eligible to be included in this Indonesian subset of DEMAND global study. The demographics, clinical characteristics and medical history of the patients are presented in Table 1 . There were more females than males, and most of the patients were in the age group of $40 \mathrm{~s}$ to $60 \mathrm{~s}$ with a mean of 57 years. The mean BMI was almost 25. The mean duration of diabetes was 6.7 years. Diabetic retinopathy was present in $16.5 \%$ of patients, almost $16 \%$ of patients had a history of CVD, and almost $20 \%$ had a history of smoking. Only $15 \%$ of patients had $\mathrm{HbA}$ recorded. Among these patients, the mean $\mathrm{HbA}$ was $8.1 \%$, and only $40 \%$ of these patients reached target level $(<7 \%)$.

Table 1. Characteristics of patients with type-2 DM

\begin{tabular}{|c|c|c|}
\hline Demographic characteristics & $\mathbf{n}$ & $(\%)$ \\
\hline Number & 770 & $(100)$ \\
\hline \multicolumn{3}{|l|}{ Gender } \\
\hline Male & 360 & $(46.75)$ \\
\hline Female & 409 & $(53.12)$ \\
\hline Missing & 1 & $(0.13)$ \\
\hline Age $(\mathrm{yrs})$ Mean $\pm \mathrm{SD}$ & $57.0 \pm 9.9$ & \\
\hline \multicolumn{3}{|l|}{ Age by decades } \\
\hline $20 \mathrm{~s}$ & 2 & $(0.26)$ \\
\hline $30 \mathrm{~s}$ & 30 & $(3.90)$ \\
\hline $40 \mathrm{~s}$ & 149 & $(19.35)$ \\
\hline $50 \mathrm{~s}$ & 269 & (34.94) \\
\hline $60 \mathrm{~s}$ & 236 & $(30.65)$ \\
\hline $70 \mathrm{~s}$ & 63 & $(8.18)$ \\
\hline $80 \mathrm{~s}$ & 6 & $(0.78)$ \\
\hline Missing & 15 & $(1.95)$ \\
\hline \multicolumn{3}{|l|}{ Clinical characteristics } \\
\hline BMI $\left(\mathrm{kg} / \mathrm{m}^{2}\right)$ Mean $\pm \mathrm{SD}$ & $24.7 \pm 4.0$ & \\
\hline BMI (Missing) & 14 & $(1.82)$ \\
\hline Duration of DM (yrs) Mean \pm SD & $6.7 \pm 5.6$ & \\
\hline Duration of DM (Missing) & $\overline{35}$ & $(4.55)$ \\
\hline $\mathrm{HbA}_{1 \mathrm{c}}(\%)$ Mean $\pm \mathrm{SD}$ & $8.1 \pm 2.1$ & \\
\hline $\mathrm{HbA}_{1 \mathrm{c}}$ at $\operatorname{target}(<7 \%)$ & 47 & $(6.10)$ \\
\hline Not at target $(\geq 7 \%)$ & 71 & $(9.22)$ \\
\hline $\mathrm{HbA}_{1 \mathrm{c}}($ Missing $)$ & 652 & (84.68) \\
\hline \multicolumn{3}{|l|}{ Medical History } \\
\hline \multicolumn{3}{|l|}{ Family history } \\
\hline Family history of DM & 329 & $(42.73)$ \\
\hline Family history of $\mathrm{CV}$ disease & 91 & $(11.82)$ \\
\hline \multicolumn{3}{|l|}{ Personal history } \\
\hline History of retinopathy & 127 & $(16.49)$ \\
\hline History of diabetic foot & 67 & $(8.70)$ \\
\hline History of $\mathrm{CV}$ disease & 121 & $(15.71)$ \\
\hline History of hyperlipidemia & 262 & (34.03) \\
\hline History of smoking & 151 & $(19.61)$ \\
\hline
\end{tabular}

$\mathrm{BMI}=$ body mass index

$\mathrm{CV}=$ cardiovascular

Medical treatments received by patients are presented in Table 2. Only $2.5 \%$ of patients did not take any antidiabetic drug. Most patients $(81.5 \%)$ took oral antidiabetics, while the rest received insulin and oral 
+ insulin combination. Almost 50\% of patients did not receive any antihypertensive drug, while around $45 \%$ received an ACEI or an ARB. Only 24\% of patients took lipid lowering drugs (mostly statins by more than $18 \%$ of patients). Among 262 (34\%) patients with hyperlipidemia, lipid lowering drugs were taken by $70 \%$ of the patients, mostly statins were taken by $54 \%$ of the patients. Antiplatelets/anticoagulants were given to about $29 \%$ of patients (mostly aspirin to about $26 \%$ of patients).

Table 2. Medical treatment in patients with type-2 DM

\begin{tabular}{|c|c|c|}
\hline Treatment & $\bar{n}$ & $(\%)$ \\
\hline \multicolumn{3}{|l|}{ Antidiabetics } \\
\hline None & 19 & $(2.47)$ \\
\hline Oral & 628 & $(81.56)$ \\
\hline Insulin & 56 & $(7.27)$ \\
\hline Oral + insulin & 53 & $(6.88)$ \\
\hline Missing & 14 & $(1.82)$ \\
\hline \multicolumn{3}{|l|}{ Antihypertensives } \\
\hline None & 367 & ( 47.66) \\
\hline Diuretics & 54 & $(7.01)$ \\
\hline ACEIs & 322 & (41.82) \\
\hline ARBs & 30 & $(3.90)$ \\
\hline ACEIs or ARBs & 349 & $(45.32)$ \\
\hline$\alpha$-blockers & 18 & $(2.34)$ \\
\hline $\mathrm{CCBs}$ & 90 & (11.69) \\
\hline Others & 11 & $(1.43)$ \\
\hline \multicolumn{3}{|l|}{ Lipid lowering drugs } \\
\hline Statins & 141 & $(18.31)$ \\
\hline Others & 44 & $(5.71)$ \\
\hline \multicolumn{3}{|l|}{ Antiplatelets/Anticoagulants } \\
\hline Aspirin & 200 & $(25.97)$ \\
\hline Warfarin & 4 & $(0.52)$ \\
\hline Other antiplatelets/anticoagulan & ts 20 & $(2.60)$ \\
\hline
\end{tabular}

$\mathrm{ACEI}=$ angiotensin-converting enzyme inhibitor $\mathrm{ARB}=$ angiotensin receptor blocker

$\mathrm{CCB}=$ calcium channel blocker

Micro/macroalbuminuria was demonstrated in $80 \%$ of patients, microalbuminuria in $60 \%$, while the remaining $20 \%$ had macroalbuminuria (Table 3 ). The estimated glomerular filtration rate (eGFR) averaged $68 \mathrm{~mL} /$ $\mathrm{min} / 1.73 \mathrm{~m}^{2}$ (data missing in $44 \%$ of patients). Among the 433 patients having eGFR values, 157 patients $(36 \%)$ had moderate stage of CKD, that is eGFR $<60$ $\mathrm{mL} / \mathrm{min} / 1.73 \mathrm{~m}^{2}$. Systolic BP reached target level $(<130$ $\mathrm{mm} \mathrm{Hg}$ ) in $30 \%$ of patients, while diastolic BP reached target level $(<80 \mathrm{~mm} \mathrm{Hg})$ in only $12 \%$ of patients, resulting $\mathrm{BP}$ goal (SBP $<130$ and $\mathrm{DBP}<80 \mathrm{~mm} \mathrm{Hg}$ ) achieved in only $9 \%$ of patients.
Table 3. Albuminuria, kidney function, and blood pressure in patients with type-2 DM

\begin{tabular}{|c|c|c|}
\hline Variable & n & $(\%)$ \\
\hline \multicolumn{3}{|l|}{ Albuminuria } \\
\hline None & 158 & $(20.52)$ \\
\hline Micro & 460 & $(59.74)$ \\
\hline Macro & 152 & $(19.74)$ \\
\hline \multicolumn{3}{|l|}{ Log2 (Albumin/creatinine ratio) } \\
\hline (mg albumin/g creatinine) & 70.8 & \\
\hline [95\% confidence interval] & {$[6.0-835]$} & \\
\hline Serum creatinine $(\mathrm{mg} / \mathrm{dL})$ Mean $\pm \mathrm{SD}$ & $1.15 \pm 0.57$ & \\
\hline Serum creatinine (Missing) & $3 \overline{3} 1$ & $(42.99)$ \\
\hline MDRD2 eGFR (mL/min) Mean \pm SD & $68 \pm 24$ & \\
\hline \multicolumn{3}{|l|}{ MDRD2 eGFR group midpoint (mL/min) } \\
\hline 20 & 20 & $(2.60)$ \\
\hline 40 & 67 & $(8.70)$ \\
\hline 60 & 161 & $(20.91)$ \\
\hline 80 & 113 & $(14.68)$ \\
\hline 100 & 50 & $(6.49)$ \\
\hline 120 & 15 & $(19.48)$ \\
\hline 140 & 2 & $(0.26)$ \\
\hline 160 & 5 & $(0.65)$ \\
\hline Missing & 337 & $(43.77)$ \\
\hline Systolic BP $(\mathrm{mm} \mathrm{Hg})$ Mean \pm SD & $137 \pm 20$ & \\
\hline Systolic BP at target $(<130 \mathrm{~mm} \mathrm{Hg})$ & 227 & $(29.48)$ \\
\hline Systolic BP not at target $(\geq 130 \mathrm{~mm} \mathrm{Hg})$ & 520 & $(67.53)$ \\
\hline Systolic BP (Missing) & 23 & ( 2.99$)$ \\
\hline Diastolic BP $(\mathrm{mm} \mathrm{Hg})$ Mean \pm SD & $84 \pm 10$ & \\
\hline Diastolic BP at target $(<80 \mathrm{~mm} \mathrm{Hg})$ & $\overline{9} 4$ & $(12.21)$ \\
\hline Diastolic BP not at target $(\geq 80 \mathrm{~mm} \mathrm{Hg})$ & 651 & $(84.55)$ \\
\hline Diastolic BP (Missing) & 25 & $(3.25)$ \\
\hline \multicolumn{3}{|l|}{ BP goal achieved $(\mathrm{SBP}<130 \mathrm{~mm} \mathrm{Hg}$ and } \\
\hline $\mathrm{DBP}<80 \mathrm{~mm} \mathrm{Hg})$ & 71 & $(9.22)$ \\
\hline BP goal not achieved & 676 & $(87.79)$ \\
\hline BP goal (Missing) & 23 & $(2.99)$ \\
\hline
\end{tabular}

\section{DISCUSSION}

This cross-sectional survey of type-2 DM patients from Indonesia without previously known proteinuria or kidney disease based on medical records - as a subset of DEMAND study - revealed that about $80 \%$ of the patients had micro- or macroalbuminuria, which were much higher than among either global (approximately $50 \%)$ or Asian patients $(56 \%){ }^{11}$

This data from Indonesia showed that both microalbuminuria (about 60\%) and macroalbuminuria (about 20\%) were much higher than either global data (about $40 \%$ and $10 \%$, respectively) or Asian data ( $43 \%$ and $12 \%$, respectively) of DEMAND study. ${ }^{11}$ The prevalence of albuminuria was indeed highest in Asian and Hispanic patients (55\% and 54\%, respectively), and lowest in Caucasians (40.6\%). ${ }^{11}$ 
In this Indonesian data, renal insufficiency was detected in about $36 \%$ of patients with available eGFR values, and this prevalence was much higher compared to $22 \%$ of global patients and 23\% of Asian patients. ${ }^{11}$ These data were in agreement with the serum creatinine levels, which averaged $1.15 \mathrm{mg} / \mathrm{dL}$ in the Indonesian patients, and $1.00 \mathrm{mg} / \mathrm{dL}$ in both Asian and global patients. ${ }^{11}$ The very high prevalence of micro- and macroalbuminuria and renal insufficiency found among these diabetic Indonesian patients not known previously to have proteinuria or kidney disease was in fact one of the highest frequencies of silent diabetic kidney disease seen in any national group in the DEMAND Study. More regular and earlier testing of MA to detect the presence of diabetic kidney disease is clearly warranted.

Previous studies have established MA as a powerful independent predictor of both renal outcomes and cardiovascular events in diabetic and non-diabetic patients. ${ }^{3-6}$ Testing for albuminuria is simple and inexpensive, and can be used to systematically screen those at immediate risk. ${ }^{12}$ The 2007 guidelines of the European Society of Hypertension and the European Society of Cardiology have now include MA in routine testing. ${ }^{13}$

In addition to the high prevalence of micro- and macroalbuminuria, the present study also showed high prevalence of several vascular risk factors, for example $\mathrm{HbA}_{1 \mathrm{c}}$ (not at target in $60 \%$ of the $15 \%$ of patients who had $\mathrm{HbA}_{1 \mathrm{c}}$ values), BP (not at target in about $90 \%$ of patients), smoking (in almost $20 \%$ of patients), and eGFR (mean $68 \mathrm{~mL} / \mathrm{min}$ in $56 \%$ of patients who had eGFR values). The Steno-2 study showed that intensive multifactorial intervention in patients with type-2 DM and MA (stepwise implementation of behaviour modification, and pharmacological therapy targeting hyperglycemia, hypertension, dyslipidemia, and MA) slowed progression to nephropathy and progression of retinopathy and autonomic neuropathy after 3.8 years of follow-up, and reduced the incidence of macrovascular complications and mortality after 7.8 years of followup..$^{14,15}$ The Steno-2 study revealed that multifactorial intervention in patients with type-2 DM and MA reduced the risk of cardiovascular and microvascular events by about $50 \% .^{15}$

Cigarette smoking is a strong and modifiable risk factor for macrovascular disease in patients with diabetes, ${ }^{16}$ and all diabetic patients who smoke should quit smoking. ${ }^{17}$ In the present study, almost $20 \%$ of patients had a history of smoking.
The mean $\mathrm{HbA}_{1 \mathrm{c}}$ in the present study was lower than that in the Steno-2 study. However, values were missing in $85 \%$ of our patients. Only $40 \%$ of the $15 \%$ of patients who had $\mathrm{HbA}$ values achieved target $\mathrm{HbA} \quad(<7 \%)$. This poor glycêmic control was due to the manicagement of glycemia was less aggressive than desired. Insulin was not used in those patients with the highest $\mathrm{HbA}_{1 \mathrm{c}}$ levels.

The $7^{\text {th }}$ report of the Joint National Committee on prevention, detection, evaluation and treatment of $\mathrm{BP}$ recommends a target $\mathrm{BP}$ below $130 / 80 \mathrm{~mm} \mathrm{Hg}$ in type- 2 diabetic patients. ${ }^{18}$ The DEMAND Study showed that most of the patients had BP above the recommended level, and $37 \%$ of these patients did not receive any antihypertensive therapy . In the present study, only $9 \%$ of the patients achieved this BP goal, and $48 \%$ of these patients did not receive BP-lowering therapy, which were common among Asian patients (49\% did not receive BP-lowering therapy). ${ }^{11}$ In fact, Asian patients received the lowest number of antihypertensive agents (average 1.5) among the other ethnics in the DEMAND Study (average 1.7). ${ }^{11}$ In line with the guideline, ${ }^{18}$ the most frequently used drugs for hypertension associated with diabetes were RAS blockers (ACEIs and ARBs), in all groups. The Asian group had the lowest utility of ACEIs or ARBs (31\%), while the Caucasian had the highest utility $(58 \%){ }^{11}$

The guideline also mention that if the BP is $20 / 10 \mathrm{~mm}$ $\mathrm{Hg}$ higher than the goal, a combination of drugs should be used, ${ }^{18}$ and that a diuretic generally should be one of the drug combination ${ }^{18}$ used for the management of hypertension in diabetic patients. ${ }^{17}$ In fact, hypertension in patients with kidney disease is hard to control without use of diuretics. And yet, diuretics were underused in the present study (only 7\%), and also in Asian subset of patients (almost 10\%). ${ }^{11}$ The Caucasians and Africans had the highest utility of diuretics $(29 \%$ and $32 \%$, respectively). ${ }^{11}$ In order to reach target BP values of $<130 / 80 \mathrm{~mm} \mathrm{Hg}$, hypertensive patients with chronic kidney disease should receive aggressive BP therapy, often with 3 or more drugs. ${ }^{18}$ With advanced renal disease (eGFR $<30 \mathrm{~mL} / \mathrm{min} / 1.73 \mathrm{~m}^{2}$ ), increasing doses of loop diuretics are usually needed in the drug combination. ${ }^{18}$

Several statin trials have demonstrated a beneficial effect on cardiovascular events, including ischemic stroke, in patients with type-2 DM without high levels of LDL-cholesterol. ${ }^{19-21}$ Since these drugs are safe, there is a strong argument that all patients with 
type-2 DM warrant statin treatment. ${ }^{22}$ Statins were only taken by $29 \%$ of patients in the DEMAND Study, by $18 \%$ of patients in Asian subset, ${ }^{11}$ and also by $18 \%$ of Indonesian patients. Even in patients with a history of hyperlipidemia, only $54 \%$ of the Indonesian patients received statins. The Caucasian had the highest utility of statins (40\%), while the African and Hispanic had the lowest utility (12-13\%). ${ }^{11}$

A large meta-analysis of the use of antiplatelet agents clearly indicated a CV benefit in diabetes. ${ }^{23}$ However, only one-third of patients in the DEMAND Study, onefourth of patients in the ASIAN subset ${ }^{11}$ and almost $30 \%$ of Indonesian patients received antiplatelets.

The present study has several limitations. ${ }^{11}$ Firstly, a single determination of urinary albumin/creatinine ratio did not fulfill the generally accepted criterion for persistent MA, requiring that 2 out of 3 determinations are within the target range. However, this requirement has been shown to reduce the point prevalence by only one-fifth. ${ }^{11}$ Secondly, this study was not population based and therefore selection bias in recruiting the centers and the diabetic patients cannot be ruled out. However, the prevalence of micro- and macroalbuminuric patients found in the Asian subset ( $55 \%$ of $\mathrm{N}=9111)$ of the DEMAND Study was comparable with the prevalence $(58.6 \%)$ observed in a cross-sectional study of 5549 type-2 diabetic patients from 10 Asian Countries using consecutive screening. ${ }^{24}$ Third, a single recording of BP did not comply with the standard measurement of BP ( 2 or more times on each of 2 or more visits). Fourth, bias was documented in relation to the missing variables, for example $\mathrm{HbA}$ and eGFR. Fifth, dosing of the different drugs was nod obtained. Finally, serum creatinine assays were not calibrated to national and preferable international reference standards.

A very high prevalence of micro- and macroalbuminuria and reduced kidney function, conditions associated with enhanced renal and CV events, was detected in type-2 diabetic Indonesian patients without prior known nephropathy. Early detection, monitoring of vascular complications, and more aggressive multifactorial treatment aiming at renal and vascular protection are urgently needed.

\section{Acknowledgements}

We thank the study patients for their participation, the study personnel for their commitment, and BristolMyers Squibb and Sanofi-Aventis for supporting the study.

\section{REFERENCES}

1. Keen H, Chlouverakis C, Fuller JH, Jarrett RJ. The concomitants of raised blood sugar: studies in newlydetected hyperglycaemics. II. Urinary albumin excretion, blood pressure and their relation to blood sugar levels. Guy's Hosp Rep. 1969; 118: 247-54.

2. Parving H-H, Mogensen CE, Jensen HAE, Evrin P-E. Increased urinary albumin excretion rate in benign essential hypertension. Lancet. 1974; 303:1190-2.

3. Viberti GC, Jarrett RJ, Mahmud U, Hill RD, Argyropoulos A, Keen H. Microalbuminuria as a predictor of clinical nephropathy in insulin-dependent diabetes mellitus. Lancet. 1982; 319: 1430-2.

4. Mogensen CE. Microalbuminuria predicts clinical proteinuria and early mortality in maturity onset diabetes. N Engl J Med. 1984; 310: 356-60.

5. Dinneen SF, Gerstein HC. The association of microalbuminuria and mortality in non-insulin-dependent diabetes mellitus. A systematic overview of the literature. Arch Intern Med. 1997; 157: 1413-8.

6. Yudkin JS, Forrest RD, Jackson CA. Microalbuminuria as a predictor of vascular disease in non-diabetic subjects. Lancet. 1988; $332:$ 530-3.

7. Ibsen $\mathrm{H}$, Olsen $\mathrm{MH}$, Wachtell K, Borch-Johnsen $\mathrm{K}$, Lindholm LM, Mogensen CE, et al. Reduction in albuminuria translates to reduction in cardiovascular events in hypertensive patients : losartan intervention for endpoint reduction in hypertension study. Hypertension. 2005; 45: 198-202.

8. Parving H-H, Lehnert H, Bröchner-Mortensen J, Gomis $\mathrm{R}$, Andersen S, Arner P. The effect of irbesartan on the development of diabetic nephropathy in patients with type-2 diabetes. N Engl J Med. 2001; 345: 870-8.

9. Ruggenenti P, Fassi A, Ilieva AP, Bruno S, Iliev IP, Brusegan $\mathrm{V}$, et al. Preventing microalbuminuria in type 2 diabetes. $\mathrm{N}$ Engl J Med. 2004; 351: 1941-51.

10. National Kidney Foundation. K/DOQI clinical practice guidelines for chronic kidney disease. Evaluation, classification, and stratification. Am J Kidney Dis. 2002; 39: S1-S266.

11. Parving HH, Lewis JB, Ravid M, Remuzzi G, Hunsicker $\mathrm{LG}$, for the DEMAND investigators. Prevalence and risk factors for microalbuminuria in a referred cohort of type 2 diabetic patients: a global perspective. Kidney Int. 2006; 69: 2057-63.

12. Remuzzi G, Weening JJ. Albuminuria as early test for vascular disease. Lancet. 2005; 365: 556-7.

13. Mancia G, De Backer G, Dominiczak A, Cifkova R, Fagard R, Germano G, et al. 2007 Guidelines for the management of arterial hypertension : the task force for the management of arterial hypertension of the European Society of Hypertension (ESH) and of the European Society of Cardiology (ESC). J Hypertens. 2007; 25: 1105-87.

14. Gaede P, Vedel P, Parving H-H, Pedersen O. Intensified multifactorial intervention in patients with type 2 diabetes mellitus and microalbuminuria: the Steno type 2 randomised study. Lancet. 1999; 353: 617-22.

15. Gaede P, Vedel P, Larsen N, Jensen GVH, Parving HH, Pedersen O. Multifactorial intervention and cardiovascular disease in patients with type 2 diabetes. N Engl J Med. 2003; 348: 383-93.

16. Haire-Joshu D, Glasgow RE, Tibbs TL. Smoking and diabetes. Diab Care. 2004; 27 (Suppl 1): S74-5. 
17. Buse JB, Ginsberg HN, Bakris GL, Clark NG, Costa F, Eckel $\mathrm{R}$, et al. American Heart Association; American Diabetes Association. Primary prevention of cardiovascular diseases in people with diabetes mellitus : a scientific statement from the American Heart Association and the American Diabetes Association. Diab Care. 2007; 30: 162-72.

18. The National High Blood Pressure Education Program Coordinating Committee. The seventh report of the Joint National Committee on prevention, detection, evaluation, and treatment of high blood pressure. JAMA. 2003; 289: 2560-71.

19. Pyörälä K, Pedersen TR, Kjekshus J, Faergeman O, Olsson AG, Thorgeirsson $G$, for the Scandinavian Simvastatin Survival Study (4S) Group. Cholesterol lowering with simvastatin improves prognosis of diabetic patients with coronary heart disease. Diab Care. 1997; 20: 614-20.

20. Heart Outcomes Prevention Evaluation (HOPE) Study Investigators. Effects of ramipril on cardiovascular and microvascular outcomes in people with diabetes mellitus: results of the HOPE study and MICRO-HOPE substudy. Lancet. 2000; 355: 253-9.

21. Heart Protection Study Collaborative Group. MRC/ BHF Heart Protection Study of cholesterol lowering with simvastatin in 20536 high-risk individuals : a randomized placebo-controlled trial. Lancet. 2002; 360: 7-22.

22. Colhoun HM, Betteridge DJ, Durrington PN, Hitman GA, Neil HAW, Livingstone SJ, et al. Primary prevention of cardiovascular disease with atorvastatin in type 2 diabetes in the Collaborative Atorvastatin Diabetes Study (CARDS): multicentre randomized placebo-controllled trial. Lancet. 2004; 364: 685-96.

23. Antithrombotic Trialists' Collaboration. Collaborative meta-analysis of randomized trials of antiplatelet therapy for prevention of death, myocardial infarction, and stroke in high risk patients. BMJ. 2002; 324 : 71-86.

24. Wu AY, Kong NC, de Leon FA, Pan CY, Tai TY, Yeung VT, et al. An alarmingly high prevalence of diabetic nephropathy in Asian type 2 diabetic patients : the MicroAlbuminuria Prevalence (MAP) Study. Diabetologia. 2005; 48: 17-26. 